\title{
Rendement van bachelor en master diploma's
}

Citation for published version (APA):

Dijksman, S., Fouarge, D., Montizaan, R., \& Steens, S. (2021). Rendement van bachelor en master diploma's. ROA. ROA Reports No. 004 https://doi.org/10.26481/umarep.2021004

Document status and date:

Published: 06/07/2021

DOI:

10.26481/umarep.2021004

Document Version:

Publisher's PDF, also known as Version of record

\section{Please check the document version of this publication:}

- A submitted manuscript is the version of the article upon submission and before peer-review. There can be important differences between the submitted version and the official published version of record.

People interested in the research are advised to contact the author for the final version of the publication, or visit the DOI to the publisher's website.

- The final author version and the galley proof are versions of the publication after peer review.

- The final published version features the final layout of the paper including the volume, issue and page numbers.

Link to publication

\footnotetext{
General rights rights.

- You may freely distribute the URL identifying the publication in the public portal. please follow below link for the End User Agreement:

www.umlib.nl/taverne-license

Take down policy

If you believe that this document breaches copyright please contact us at:

repository@maastrichtuniversity.nl

providing details and we will investigate your claim.
}

Copyright and moral rights for the publications made accessible in the public portal are retained by the authors and/or other copyright owners and it is a condition of accessing publications that users recognise and abide by the legal requirements associated with these

- Users may download and print one copy of any publication from the public portal for the purpose of private study or research.

- You may not further distribute the material or use it for any profit-making activity or commercial gain

If the publication is distributed under the terms of Article $25 \mathrm{fa}$ of the Dutch Copyright Act, indicated by the "Taverne" license above, 
Maastricht University

\section{Rendement van bachelor en master diploma's}

Sander Dijksman

Didier Fouarge

Raymond Montizaan

Sanne Steens

\section{ROA Rapport}

ROA-R-2021/4

Researchcentrum voor Onderwijs en Arbeidsmarkt | ROA Research Centre for Education and the Labour Market / ROA 


\title{
Colofon
}

(c) Researchcentrum voor Onderwijs en Arbeidsmarkt (ROA). Niets uit deze uitgave mag op enige manier worden verveelvoudigd zonder voorafgaande schriftelijke toestemming van de directeur van het ROA.

\author{
Researchcentrum voor Onderwijs en Arbeidsmarkt \\ Postbus 616 \\ 6200 MD Maastricht \\ $\mathrm{T}+31433883647$ \\ $\mathrm{F}+31433884914$ \\ secretary-roa-sbe@maastrichtuniversity.nl \\ www.roa.nl \\ School of Business and Economics \\ Maastricht University \\ Vormgeving \\ ROA secretariaat, Maastricht
}

ISBN: 978-90-5321-604-0

ISSN: 2666-8858

Juni 2021

\section{NRO)}

Dit rapport is onderdeel van een onderzoek dat gefinancierd wordt door het Nationaal Regieorgaan Onderwijsonderzoek. 


\section{Inhoud}

Resumé

$1 \quad$ Inleiding 1

2 Ontstaan van de BAMA-structuur en impact op het onderwijs 3

2.1 Ontstaan van de BAMA-structur 3

2.2 BAMA-structuur en impact op het onderwijs 4

3 De vraag naar bachelor en master gediplomeerden 5

$\begin{array}{lll}3.1 & \text { Tekstmining } & 5\end{array}$

$\begin{array}{ll}3.2 \text { Vacatures } & 6\end{array}$

4 Doorstroommogelijkheden binnen de BAMA-structuur 11

5 Arbeidsmarktrendement in de BAMA-structuur $\quad 15$

$\begin{array}{lll}5.1 & \text { Arbeidsmarktstatus } & 16\end{array}$

5.2 Bruto uurloon van bachelor en master gediplomeerden $\quad 20$

6 Conclusie 25

$\begin{array}{lr}\text { Literatuur } & 27\end{array}$

$\begin{array}{lr}\text { Bijlage } & 29\end{array}$ 


\section{Resumé}

Dit rapport gaat in op het arbeidsmarktrendement van bachelor en master diploma's uit het hbo en wo. Aan de vraagkant onderzoeken wij door middel van tekstmining in welke mate werkgevers die op Academic Transfer en Indeed werven in hun zoektocht naar hoogopgeleiden verwijzen naar bachelor en master diploma's in hun vacaturetekst. We concluderen dat dit niet of nauwelijks het geval is: werkgevers in Nederland werven 18 jaar na de invoering van de BAMA structuur nog steeds aan de hand van termen zoals hbo- en wo-gediplomeerden.

Wo-masters hebben ten opzichte van hbo-bachelors een $7,7 \%$ hogere kans om 1 jaar na diplomering een baan te hebben. Ze zijn daarentegen minder vaak werkzaam als zelfstandige en studeren minder vaak door dan hbo-bachelor gediplomeerden. Hbo-master gediplomeerden zijn significant minder vaak werkzaam als werknemer in loondienst en studeren minder door, maar zijn juist vaker werkzaam als zelfstandige dan hbo-bachelor gediplomeerden.

Voor de verdiensten in een baan is de hoogte van het opleidingsniveau (hbo of wo) nog steeds de meest bepalende factor is. Wo-master gediplomeerden verdienen het meest. 5 jaar na diplomering verdienen zij 22\% meer dan hbo-bachelor gediplomeerden. Dit is een aanzienlijk verschil in het rendement. Hbo-master gediplomeerden verdienen daarentegen ongeveer evenveel als hbo bachelors en dus beduidend minder dan wo-master gediplomeerden. Voor wo-bachelor gediplomeerden zien we dat het loon eveneens substantieel lager is dan voor wo-master gediplomeerden, en onze analyses laten zien dat een groot deel van de wo-bachelor gediplomeerden enige jaren na diplomering alsnog een wo-master vervolgopleiding gaan volgen. Het rendement voor de wo-bachelors en de hbo-masters moet echter met enige voorzichtigheid worden geïnterpreteerd vanwege de grote selectiviteit in deze groepen. 



\section{Inleiding}

In 1999 werd de Bolognaverklaring getekend door een deel van de Europese ministers van Onderwijs. Deze verklaring was het begin van het Bolognaproces wat als doel had om het Europese hogere onderwijs te herorganiseren tot een coherent en uitwisselbaar systeem (Lipnicka, 2016; Teelken, 2019). Er werd gekozen voor een Angelsaksisch onderwijssysteem, het zogenaamde Bachelor-Mastersysteem (BAMA). Met de invoering van de BAMA-structuur in schooljaar 2002-2003 is de structuur van het hoger onderwijs in Nederland veranderd naar twee losstaande cycli (bachelor, master) met diploma's die door heel Europa vergelijkbaar zijn. Later is hier een derde cyclus aan toegevoegd voor het doctoraat (Wihlborg, \& Teelken, 2014).

De diploma's die voortvloeien uit deze cycli dienen elk als startkwalificatie voor de arbeidsmarkt, maar maken het ook mogelijk om door te studeren op een hoger niveau. De doorstroommogelijkheden binnen het onderwijs zijn door de invoering van de BAMA-structuur veranderd. Zo kunnen studenten met een hbo-bachelor diploma bijvoorbeeld doorstromen naar een wo-master (eventueel na een pre-master) en studenten met een hbo-propedeuse naar een wo-bachelor. Daarnaast is het mogelijk om zowel in het hbo als wo gelijkwaardige diploma's te halen. In de BAMA-structuur zijn wo-bachelors en hbo-bachelors in principe gelijkwaardig en hetzelfde geldt voor masterdiploma's op hbo- en wo-niveau.

De vraag is echter of de economische waarde van deze diploma's gelijk zijn aan elkaar. In dit onderzoek gaan wij in op de volgende vragen:

1. In welke mate werven werkgevers in Nederland bachelor en master gediplomeerden?

2. Wat zijn de stromen van studenten in de BAMA structuur?

3. Is er sprake van een verschil in het arbeidsmarktrendement (in termen van baankans en loon) tussen een bachelor en master diploma's uit hbo en wo? En in welke mate hebben afwijkende vooropleidingstrajecten een invloed op dit rendement? 
Het voorliggende rapport gaat in op deze vragen door allereerst de rol die het opleidingsniveaus speelt in de vraag naar arbeid te onderzoeken. ${ }^{1}$ Door middel van tekstmining onderzoek naar niveau-aanduidingen in vacatureteksten wordt een beeld gegeven van de rol van opleidingsniveau in vacature van werkgevers en de mate waarin deze vacatures verwijzen naar bachelor en master kwalificaties. De tekstmining-technieken worden toegepast op vacatures van Academic Transfer en Indeed. Er wordt onderzocht hoe de verdeling van niveau-aanduidingen is opgebouwd en of er wordt geworven op bachelor- of master-niveau en of dat dit nog gebeurt op wo- of hbo-niveau.

Ten tweede, doordat bachelorsdiploma's van het hbo en wo in theorie gelijkwaardig zijn (waarbij hbo vooral is gericht op beroepspraktijk en wo een academische insteek heeft) en een hbo-propedeuse toelating biedt tot een wo-bachelor, is het doorstromen binnen het hoger onderwijs toegankelijker gemaakt. Het is derhalve relevant om de doorstroom binnen de BAMA-structuur in kaart te brengen. In dit rapport onderzoeken wij de stromen in het hoger onderwijs aan de hand van administratieve data van CBS en DUO op persoonsniveau. DUO is de organisatie die onderwijsgegevens registreert van studenten die ingeschreven zijn aan bekostigde Nederlandse onderwijsinstellingen. De data van het CBS betreft onder andere informatie van de Gemeentelijke Basisadministratie Personen (GBA) die wij koppelen aan microdata uit het Stelsel van Sociaal-statistische Bestanden (SSB) alsook aan de DUO-data.

Ten derde wordt het arbeidsmarktrendement geanalyseerd op basis van administratieve data van CBS en DUO op persoonsniveau. Ons onderzoek richt zich op de kans op werk, kans op werken als zelfstandige, de kans op uitkering en het loon van gediplomeerden 1, 2 en 5 jaar na diplomering. We analyseren het rendement van bachelors en masters, voor zowel hbo als wo die zijn afgestudeerd in cohort 2012-2013. Dit is de eerste groep waarvoor zowel op korte termijn alsook 5 jaar na diplomering het rendement kan worden vastgesteld.

Het rapport is als volgt gestructureerd. Eerst wordt er in hoofdstuk 2 een korte inleiding gegeven over het ontstaan van de BAMA-structuur in de context van de Bolognaverklaring. Ook bespreken we de impact op het onderwijs in Nederland. Hoofdstuk 3 bespreekt de vraagkant door middel van analyses van vacature teksten. De verschillende doorstroommogelijkheden binnen de BAMA-structuur komen aan bod in hoofdstuk 4. Daarna volgt in hoofdstuk 5 een analyse van het arbeidsmarktrendement van de verschillende diploma's in het hoger onderwijs. De analyses richten zich op de kans op werk en de hoogte van het loon op 1, 2 en 5 jaar na diplomering. Ten slotte sluit dit rapport af met een conclusie.

1 Dit rapport is geschreven als onderdeel van het Project Onderwijs-Arbeidsmarkt (POA). POA door NRO bekostigd (dossiernummer 405-17- 900) met bijdragen van het Ministerie van OCW, het Ministerie van Landbouw, Natuur en Voedselkwaliteit (LNV), het Ministerie van Binnenlandse Zaken en Koninkrijksrelaties (BZK) en het Ministerie van Sociale Zaken en Werkgelegenheid (SZW), almede met aanvullende bekostiging daar het UWV Werkbedrijf, de stichting Samenwerking Beroepsonderwijs Bedrijfsleven (SBB), en Randstad Nederland. https://www.roa.nl/research/research-projects/project-onderwijs-arbeidsmarkt-poa 


\section{Ontstaan van de BAMA-structuur en impact op het onderwijs}

\subsection{Ontstaan van de BAMA-structuur}

In 1999 werd de Bolognaverklaring getekend door een deel van de Europese ministers van Onderwijs. Het aantal deelnemende landen is bij tussentijdse vergaderingen gestegen. Tot op heden is de Bolognaverklaring door 49 verschillende landen getekend (Europese Commissie, z.d.). Deze verklaring was het begin van het Bolognaproces wat als doel had om het Europese hogere onderwijs te herorganiseren tot een coherent en uitwisselbaar systeem (Lipnicka, 2016; Teelken, 2019).

Het streven van deze verklaring was om een onderwijssysteem bestaande uit drie losstaande cycli te vormen (bachelor, master en doctoraat) met diploma's die door heel Europa vergelijkbaar zijn (de BAMA-structuur). Deze structuur zou de flexibiliteit in het hoger onderwijs verhogen waardoor studenten mobieler zijn en gemakkelijker kunnen inspelen op de behoeften van de arbeidsmarkt.

De BAMA-structuur maakt het mogelijk om opleidingen aan verschillende onderwijsinstituten in binnen- en buitenland te volgen. Zo wordt de internationalisering (academische mobiliteit en samenwerking van zowel studenten als wetenschappelijk personeel) bevorderd (Lipnicka, 2016; Teelken, 2019). Een nauwe samenwerking en duidelijke afstemming van de invulling van de opleidingen tussen de deelnemende landen is hiervoor vereist. Zo wordt er ruim aandacht besteed aan motivatie om te blijven ontwikkelen (Leven Lang Ontwikkelen), internationale kennisdeling en ook zeker aan onafhankelijke kwaliteitscontrole van de opleidingen (EUR-Lex, 2015; Teelken, 2019). In Nederland en Vlaanderen wordt de kwaliteitscontrole bijvoorbeeld verzorgd door het NVAO (Nederlands-Vlaamse Accreditatieorganisatie).

Met de invoering van de BAMA-structuur in het academisch jaar 2002-2003 in Nederland, zijn alle opleidingen in het hoger onderwijs overgestapt op een Europees studiepuntensysteem, het ECTS (European Credit Transfer System). Dankzij de invoering van het ECTS kunnen studenten flexibeler gebruik maken van de BAMA-structuur. De invoering van de ECTS maakt het bijvoorbeeld gemakkelijk mogelijk om een semester aan een ander onderwijsinstituut in Nederland of in het buitenland te volgen en de credits te integreren in de bachelor of master. Een studiejaar bestaat uit 60 ECTS, dus een wo-bachelor bestaat in de regel uit 180 ECTS, een hbo-bachelor uit 240 ECTS en een (éénjarige) master uit 60 ECTS. Hier zijn echter uitzonderingen op te vinden, zo duurt een medische opleiding of researchmaster vaak langer (Bosch-Chapel, 2016; Inspectie van het Onderwijs, 2008). 


\subsection{BAMA-structuur en impact op het onderwijs}

De invoering van de BAMA-structuur had dus als belangrijkste doel om de flexibiliteit in het hoger onderwijs te verhogen. Het CPB heeft onlangs een notitie uitgebracht waarin is onderzocht in hoeverre de nagestreefde doelen van de BAMA-structuur zijn volbracht (Bolhaar, \& Swart, 2020). Deze notitie stelt dat de flexibiliteit op vier verschillende manieren kan worden gemeten, namelijk; wanneer, wat, en waar er gestudeerd wordt, tezamen met de keuzemogelijkheden in opleidingen in het hoger onderwijs die studenten hebben. Het rapport van het CPB laat zien dat de flexibiliteit in wanneer mensen studeren nog weinig veranderd lijkt te zijn. Studenten kiezen vaker voor een tussenjaar tussen hun bachelor en master, maar de meeste studenten in het hoger onderwijs zijn relatief jong. Dit suggereert dat men het potentieel van de BAMA structuur voor Leven Lang Ontwikkelen niet volledig benut.

Er is wel een verhoogde flexibiliteit waarneembaar in wat en waar er gestudeerd wordt. Doordat bachelor- en masteropleidingen niet meer onlosmakelijk aan elkaar verbonden zijn, is het mogelijk voor studenten om ervoor te kiezen om hun master in een ander vakgebied te volgen. Van deze mogelijkheid wordt door steeds meer studenten gebruik gemaakt, dit percentage is namelijk vanaf de invoering van de BAMA-structuur tot nu met $15 \%$ gestegen (naar 35\%). Ditzelfde geldt ook voor de instelling waar studenten hun opleiding volgen. Het is immers niet enkel mogelijk om te veranderen van richting, maar ook van instelling. Het is ook mogelijk dat studenten ervoor kiezen om hun master aan een andere instelling te volgen dan waar ze hun bacheloropleiding hebben gevolgd. Dit percentage is ongeveer verdrievoudigd naar $20 \%$ sinds de invoering van de BAMA structuur. Er zijn ook steeds meer studenten die besluiten om bijvoorbeeld hun master in het buitenland te volgen, zo zijn er desgelijks steeds meer buitenlandse studenten die in Nederland hun opleiding in het hoger onderwijs volgen (Bolhaar, \& Swart, 2020).

Deze resultaten moeten echter voorzichtig worden geïnterpreteerd, aangezien de analyses niet causaal zijn. Ook is er geen vergelijkbare data beschikbaar van voor de invoering van de BAMA-structuur. Om deze redenen is het niet mogelijk om veranderingen in zijn volledigheid toe te kennen aan de invoering van de BAMA-structuur (Bolhaar, \& Swart, 2020).

Ons onderzoek vult het bestaande onderzoek naar de effecten van de invoering van de BAMA-structuur aan door onderzoek te doen naar de vraag naar bachelor- en mastergediplomeerden op de arbeidsmarkt, doorstroom in het onderwijs en door het rendement op bachelor- en master-diploma's in kaart te brengen. 


\section{De vraag naar bachelor en master gediplomeerden}

Op de arbeidsmarkt worden vraag en aanbod van kennis en vaardigheden op elkaar afgestemd. Voor werkgevers zijn de taken die op het werk gedaan moeten worden bepalend voor hun vraag naar kennis en vaardigheden. Als deze taken goed aansluiten bij datgene dat geleerd is in de opleiding, dan zal dit een gunstig effect hebben op het rendement van de opleiding. Anderzijds, zal het rendement ook worden beïnvloed door het aanbod van het aantal studenten. In het geval van de analyse naar de impact van de invoering van de BAMA-structuur op het rendement van opleidingen is het relevant om beide kanten van de arbeidsmarkt te belichten. Een open vraag is in welke mate de beoogde flexibiliteit van de BAMA structuur van invloed is op hoe werkgevers hun behoefte aan kennis en vaardigheden verwoorden in hun vacatures. In dit hoofdstuk gaan wij in op de mate waarin werkgevers termen als bachelor en of master gebruiken in hun zoektocht naar hooggekwalificeerd personeel.

\subsection{Tekstmining}

De arbeidsmarktvraag komt tot uiting in het aantal vacatures die beschikbaar zijn op de arbeidsmarkt. Om te onderzoeken in hoeverre de BAMA-structuur van invloed is op vraag van werkgevers, hebben we de vacatureteksten van zowel Academic Transfer als Indeed geanalyseerd door middel van tekstmining onderzoek naar niveau-aanduidingen in vacatureteksten. Werkgevers plaatsen hun vacatures voor het overgrote merendeel online, waardoor op een snelle manier een groot publiek wordt bereikt. In deze vacatureteksten wordt doorgaans ook een niveauaanduiding geplaatst die hoort bij de beoogde baan. Het feit dat vacatures doorgaans online worden geplaatst in combinatie met dat niveauaanduidingen vrij standaard zijn betekent dat tekstmining onderzoek een waardevol instrument is om de vacatures en de arbeidsmarktvraag in kaart te brengen. De combinatie van Academic Transfer en Indeed wordt gebruikt om een zo breed mogelijk scala aan vacatures en niveauaanduidingen te verzekeren. ${ }^{2}$

Specifiek hebben we onderzocht hoe de verdeling van niveau-aanduidingen is opgebouwd binnen de vacatureteksten en of er wordt geworven op bachelor- of masterniveau en of dat dit nog gebeurt op wo- of hbo-niveau. Daartoe hebben we een proces toegepast dat bestaat uit vier stappen: informatie extractie, data structureren, data categoriseren en data analyseren. Eerst wordt de informatie geëxtraheerd door de websites

2 Waar de vacatureteksten op Academic Transfer zeer gestructureerd zijn qua niveauaanduiding, is dit bij Indeed in mindere mate het geval. 
van Academic Transfer en Indeed door te zoeken met behulp van webscraping. ${ }^{3}$ Deze webscraping haalt de benodigde informatie (bijvoorbeeld: titel van de baan, omschrijving, organisatie, niveauaanduiding en locatie) van elke vacaturepagina en zet dit om naar een dataset.

Nadat de informatieverzameling compleet is, dient de dataset gestructureerd en opgeschoond te worden, dit heet data cleaning. Dit gebeurt door middel van tekstmining. Tekstmining identificeert relevante informatie in ongestructureerde teksten. Om dit te kunnen doen, moet er zoveel mogelijk ruis uit deze ongestructureerde data worden gehaald. Zo worden de stopwoorden verwijderd, werkwoorden worden omgezet naar hun stam, interpunctie en nummers worden verwijderd en geanalyseerd welke woorden vaak voorkomen in de vacatureteksten.

Vervolgens wordt de data gecategoriseerd. In de opgeschoonde data wordt voor elke vacature de baanomschrijving geanalyseerd op niveauaanduidingen, deze gevonden niveauaanduidingen worden geclassificeerd en geanalyseerd.

\subsection{Vacatures}

Bij Academic Transfer bestaat een vaste structuur waarin alle hoofdspecificaties zijn gegroepeerd, waaronder de niveauaanduidingen. De verdeling van de niveauaanduidingen over de vacatures wordt weergegeven in figuur 3.1.

Dezelfde exercitie is ook uitgevoerd bij vacatureteksten op Indeed, dat breder gebruikt wordt dan enkel door kennisinstellingen. De niveauaanduidingen worden hier vastgesteld door het laagste niveau dat wordt vermeld in de vacaturetekst. Als een vacaturetekst bijvoorbeeld spreekt over een mbo- en een hbo-opleiding, dan wordt de niveauaanduiding geclassificeerd als mbo. De verdeling van deze niveauaanduidingen die hierbij zijn geconstateerd zijn weergegeven in figuur 3.2.

3 De vacature teksten op Academic Transfer zijn verzameld in november 2019 en maart 2020. Die op Indeed in april 2020. 


\section{Figuur 3.1}

Verdeling niveauaanduidingen vacatures Academic Transfer (Aantal: 559, verzameld in november 2019 en maart 2020)

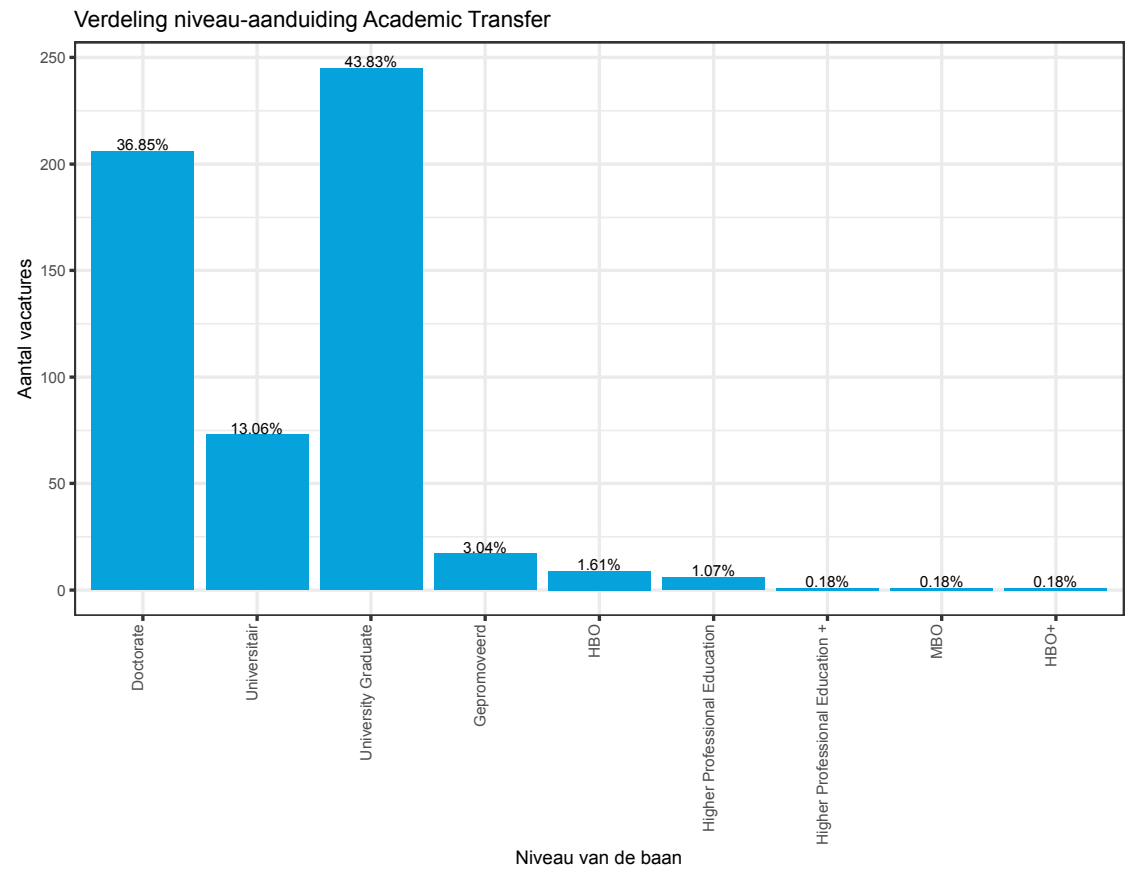

Bron: Academic Transfer, bewerking ROA 
Figuur 3.2

Verdeling niveauaanduidingen vacatures Indeed (Aantal: 913, verzameld in april 2020)

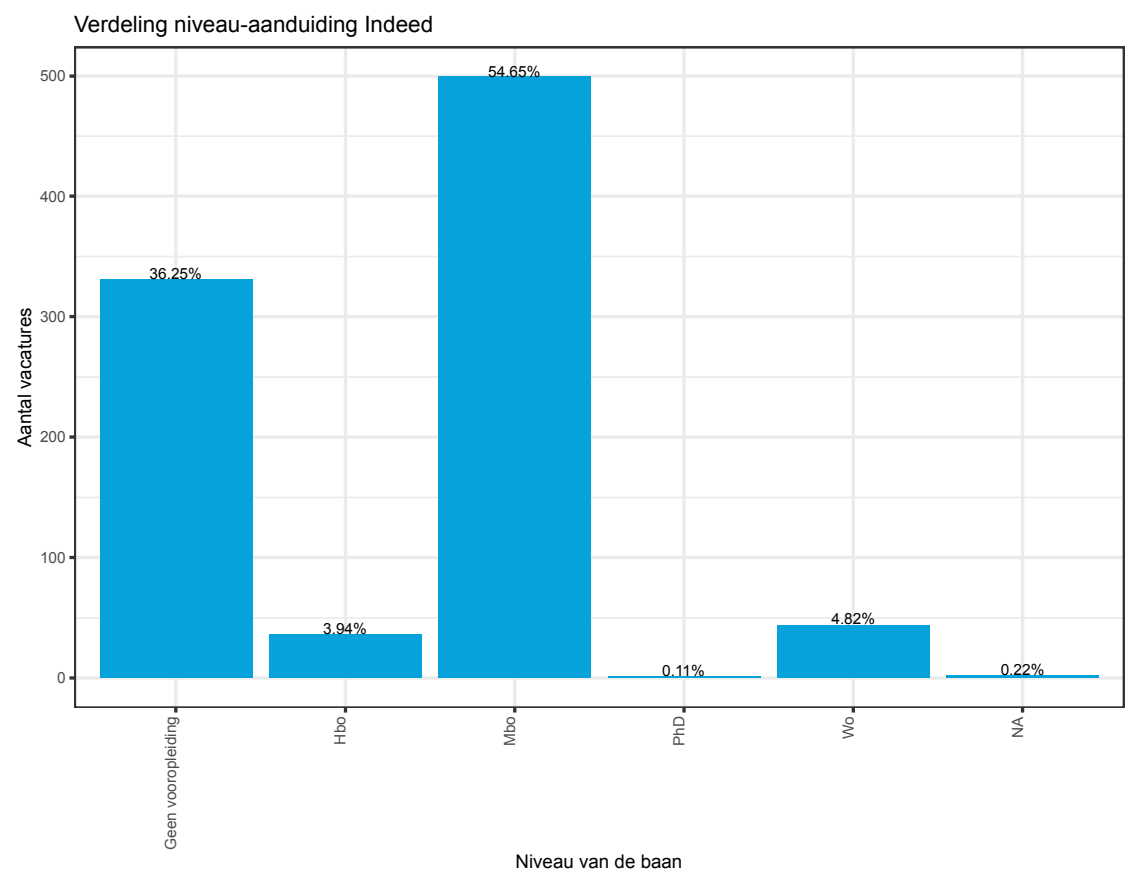

Bron: Indeed, bewerking ROA

De verdeling van niveauaanduidingen bij Indeed verschilt van die van Academic Transfer. Zo bestaat de mogelijkheid dat werkgevers vragen om een bachelor diploma. Echter ook bij Indeed zien we dat voornamelijk geworven wordt op basis van mbo, hbo en wo niveau. Slechts $0.88 \%$ van de vacatures wordt geclassificeerd als bachelor-niveau. Aangezien Indeed geen vaste structuur heeft waar de niveauaanduidingen worden geplaatst, hebben we een aanvullende analyse gedaan waarbij de gehele vacaturetekst wordt doorzocht op niveauaanduidingen binnen de vacaturegroepen (de laagste niveauaanduiding in de vacaturetekst). De resultaten hiervan worden getoond in figuur 3.3

Figuur 3.3 toont dat er binnen de geanalyseerde vacatures van Indeed regelmatig verschillende niveauaanduidingen worden gebruikt binnen een vacaturetekst. Binnen de mbo-vacatures wordt ook regelmatig gesproken over hbo-niveau Dit zijn vaak vacatures waarvoor het niveau tussen mbo en hbo in zit. Echter, uit de figuur valt ook op te maken dat werkgevers amper werven aan de hand van termen als bachelor of master gediplomeerden. Werkgevers gebruiken doorgaans een niveauaanduiding die reeds vóór de BAMA-structuur werd gehanteerd: hbo- of wo-niveau. 


\section{Figuur 3.3}

Verdeling van de genoemde opleidingsniveaus per vacaturegroep Indeed (Aantal: 913, verzameld in april 2020)

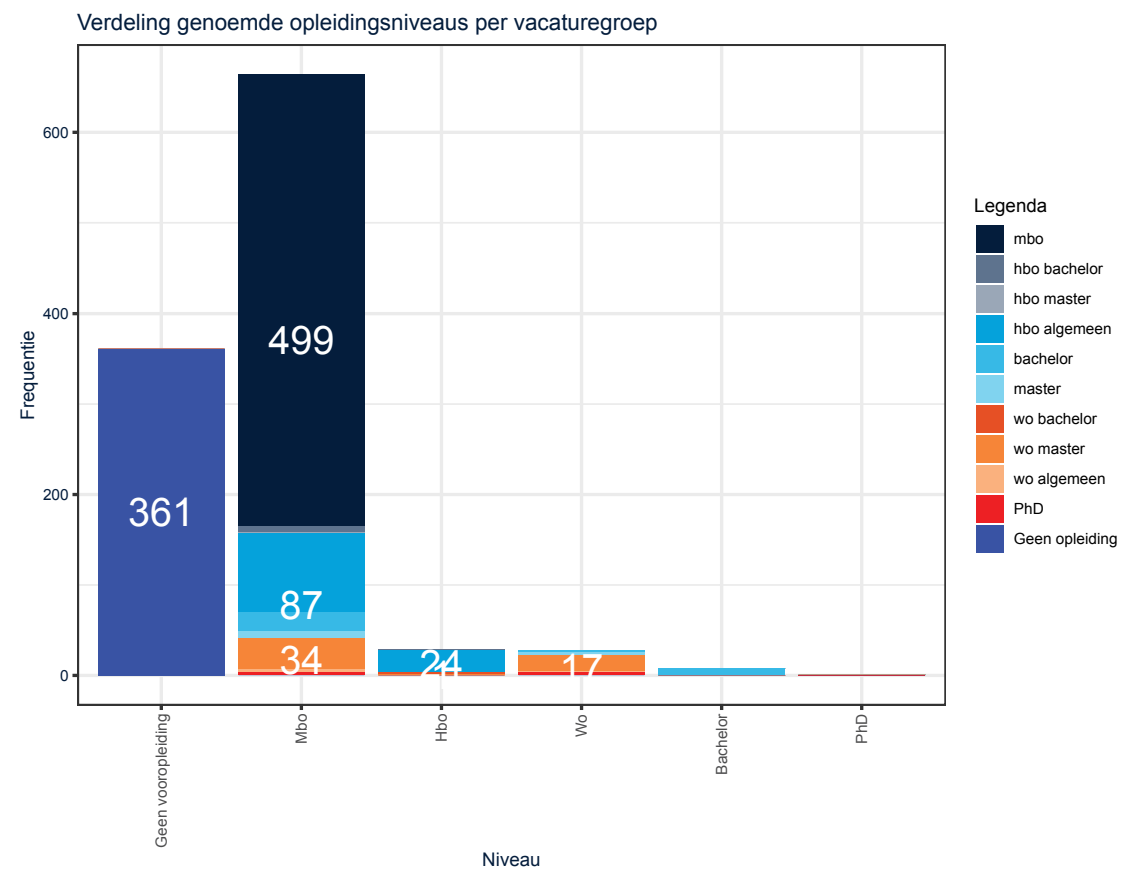

Bron: Indeed, bewerking ROA

De conclusie die uit de toepassing van de tekstmining technieken kan worden getrokken is dus dat de BAMA-structuur nog niet is ingeburgerd bij werkgevers. Er wordt vrijwel altijd specifiek gevraagd naar een hbo- of wo-niveau en slechts zelden naar enkel een bachelor of master. Dit betekent waarschijnlijk dat werkgevers er dus ook vanuit gaan dat de meeste wo-studenten zowel een bachelor als een masterdiploma afronden.

De wijze waarop werkgevers hun vacatures opstellen zal ook gevolgen hebben voor hoe gediplomeerden zich binnen de BAMA-structuur ontwikkelen. Werknemers en studenten zien dat werkgevers in vacatures een duidelijk onderscheid maken tussen gediplomeerden van een hbo-instelling en die van een wo-instelling. Dit kan ervoor zorgen dat studenten ook een afweging maken tussen een hbo en wo diploma en zelf ook niet geneigd zijn te denken in termen van hun kansen op de arbeidsmarkt bij het behalen van een bachelor of master diploma. Doorstroom keuzen worden besproken in het volgende hoofdstuk. De vraag die dit vervolgens oproept is of er ook verschillen vallen waar te nemen in het rendement van een bachelor of masterdiploma (van hbo of wo) op de arbeidsmarkt. Dit wordt onderzocht in hoofdstuk 5. 



\section{Doorstroommogelijkheden binnen de BAMA-structuur}

Volgens de BAMA-structuur zijn hbo-bachelors en wo-bachelors in theorie gelijk, en dit geldt ook voor hbo en wo master diploma's. Hoofdstuk 3 laat zien dat dit in de praktijk nog niet het geval is in de percepties van werkgevers: zij werven niet in termen van bachelor en master diploma's. Werkgevers nemen liever een master gediplomeerde dan een bachelor gediplomeerde aan (Humburg, \& Van der Velden 2014; al wordt daar geen onderscheid gemaakt tussen hbo en wo). En ook in het onderwijsstelsel zelf worden er nog barrières opgeworpen die een volledige gelijkschakeling in de weg staan. Bijvoorbeeld, als een student met een hbo-bachelor diploma een wo-master wil volgen, dient er vaak vooraf een schakelprogramma, een zogenaamde premaster, te worden voltooid. Deze programma's zijn vaak speciaal opgesteld om het verschil in academische vaardigheden te verkleinen voor hbo-doorstromers naar het wo onderwijs. Bovendien, tot op heden laat één op de vijf wo-masteropleidingen nog geen hbo-gediplomeerden toe (Inspectie van het Onderwijs, 2019). Het aanbod in hbo-masters is daarnaast ook nog erg beperkt vergeleken met het aanbod in wo-masters. Hbo-bachelor gediplomeerden zien voornamelijk vaak af van een wo-master omdat ze niet geïnteresseerd zijn of hun diploma als voldoende kwalificatie achten voor toetreding tot de arbeidsmarkt. Een andere (toenemende) reden is de groeiende studieschuld (van den Broek et al., 2020).

Desondanks heeft de BAMA-structuur er wel voor gezorgd dat studenten makkelijker kunnen doorstromen. Studenten met een hbo-bachelor diploma kunnen bijvoorbeeld doorstromen naar een wo-master (dankzij de premaster) en studenten met een hbopropedeuse naar een wo-bachelor. Deze doorstroom kan van belang zijn voor het arbeidsmarktrendement. Immers, het rendement wordt door zowel vraag als aanbodfactoren bepaald. Het is derhalve relevant om de doorstroom binnen de BAMA-structuur in kaart te brengen. In dit hoofdstuk wordt op basis van administratieve data van CBS en DUO op persoonsniveau de doorstromingen in kaart gebracht. De doorstroom in het hoger onderwijs wordt geanalyseerd voor het cohortjaar 2012-2013. Dit omdat voor dit cohort in hoofdstuk 5 het rendement voor hetzelfde cohort wordt bepaald voor een periode van 5 jaar na diplomering.

De doorstroom in de BAMA-structuur wordt weergegeven in figuur 4.1. De doorstroom die wij laten zien heeft betrekking op voltijdsgediplomeerden die in cohort 2012-2013 een diploma hebben behaald in het hoger onderwijs dat niet hun laatste diploma is en alsnog doorstromen naar een vervolgopleiding. 
Figuur 4.1 laat zien dat de grootste stromen zich binnen het hbo of wo afspelen, en dat de stromen van hbo naar wo relatief klein zijn. De grootste doorstroom zijn die van de propedeuse naar bachelor-diploma en van bachelor naar masterdiploma. Van alle studenten die na het behalen van hbo-bachelor propedeuse doorstuderen, haalt 92\% een hbo-bachelor diploma. Opmerkelijk is dat slechts een minimaal aandeel hbobachelor gediplomeerden kiest voor een hbo-master. Een mogelijke reden hiervoor is het beperkte aanbod van hbo-masters, dat ook nog domein-specifiek is (educatief, kunst, verpleegkundigen). Het grootste aandeel doorstromers vanuit een hbo-bachelor kiest wel vaak voor een wo-master (4187 studenten). Dit omdat werkgevers vaker vragen naar een universitaire master dan haar hbo-equivalent zoals is gebleken uit de vacature analyses van dit rapport. Echter ten aanzien van het totaal aantal wo-ers is deze groep alsnog relatief klein.

\section{Figuur 4.1}

Voltijdsgediplomeerden uit ho die na 2012-2013 doorstromen naar een andere opleiding in het ho (zonder hbo-associate degree)

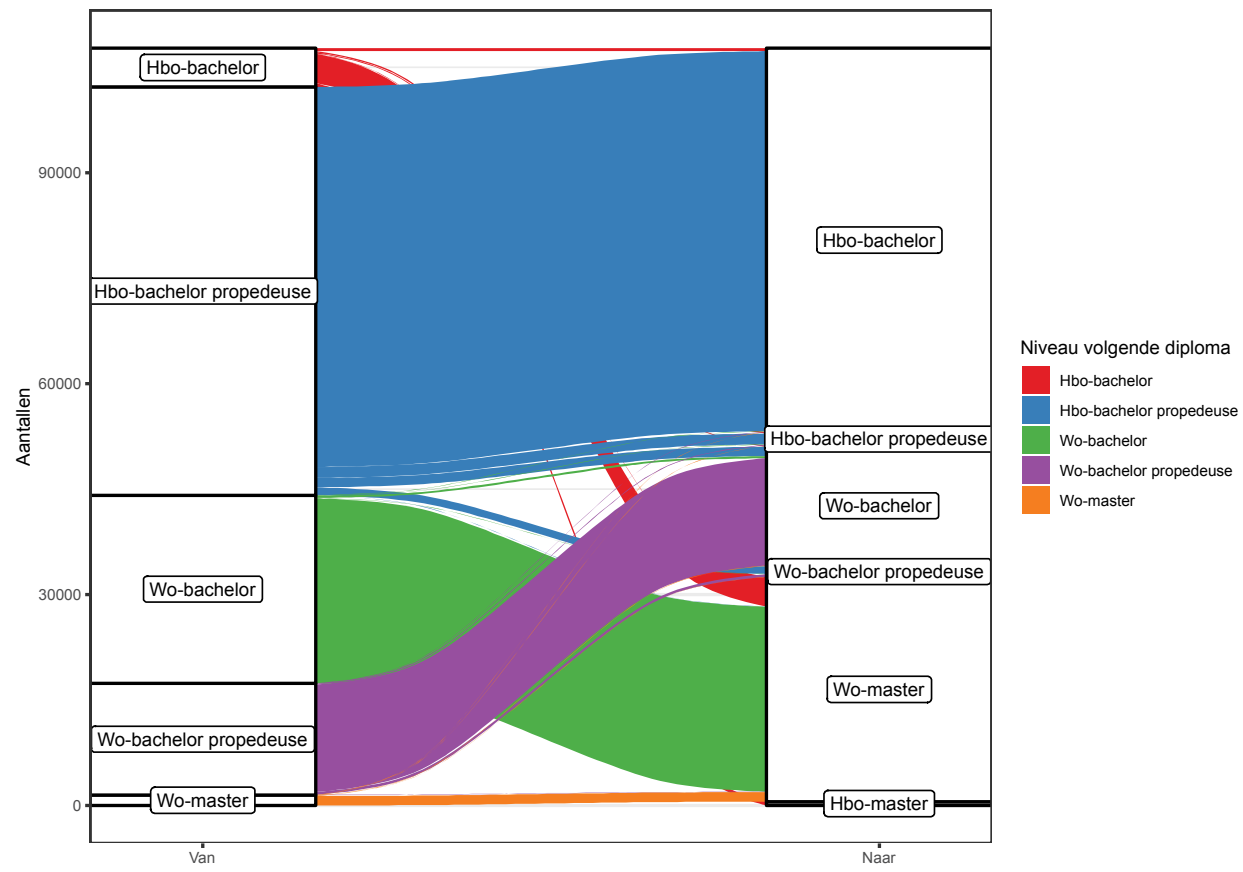

Bron: CBS-microdata, bewerking ROA

Flexibiliteit in de BAMA structuur kan ook inhouden dat studenten besluiten een vervolgstudie te volgen in een andere richting. We definiëren een vervolgstudie in een 
andere richting als deze niet tot dezelfde ISCED-field 2013 classificatie behoort. ${ }^{4}$ In figuur 4.2 wordt daarom de doorstroom uitgesplitst naar studenten die hun volgende diploma in hun eigen richting volgen of in een andere richting.

Figuur 4.2 toont dat in cohort 2012-2013 het overgrote aandeel kiest voor een vervolgopleiding in dezelfde richting. Dit is vooral het geval bij propedeusediploma's, maar aanzienlijk minder bij bachelor- of masterdiploma's. Zo studeert bijna $20 \%$ van de wo-bachelor doorstromers door naar een wo-master in een andere richting. Dit komt overeen met de resultaten van de CPB-notitie die eerder in dit rapport werden besproken (Bolhaar, \& Swart, 2020). De hbo-bachelors die doorstromen naar een wo-master kiezen zelfs in ruim $40 \%$ van de gevallen voor een wo-master in een andere richting. Dit wordt nog overtroffen door de wo-masters die nog een volgend wo-masterdiploma halen, van deze groep kiest bijna 53\% voor een wo-master in een andere richting. Hoewel de doorstroom dus beperkt is in de BAMA-structuur, is er dus wel een niet te verwaarlozen flexibiliteit in studierichtingen. Dit laatste kan ertoe bijdragen dat de BAMA-structuur leidt tot een betere afstemming tussen de vraag-en aanbod op de arbeidsmarkt.

\section{Figuur 4.2}

Voltijdsgediplomeerden uit hbo of wo die na 2012-2013 doorstromen naar een andere opleiding in het hbo of wo (zonder hbo-associate degree), uitgesplitst naar richtingverandering

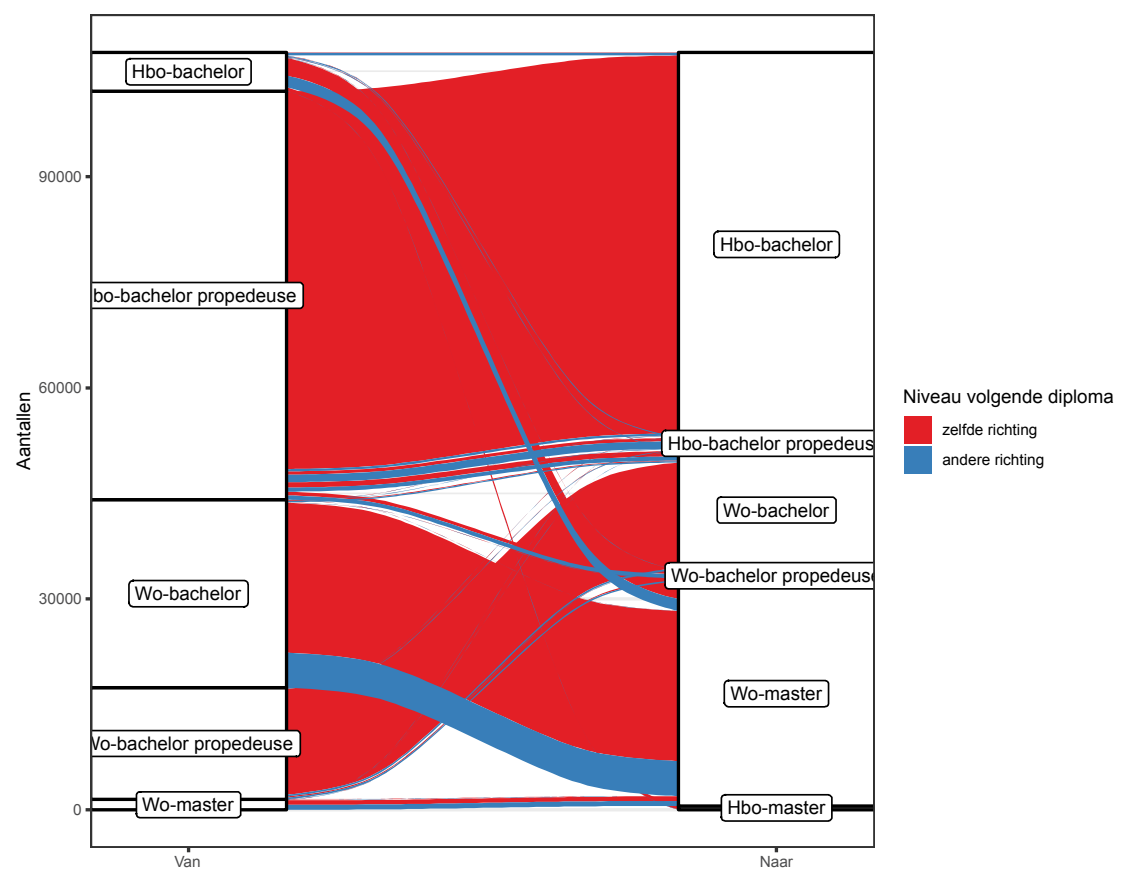

Bron: CBS-microdata, bewerking ROA

$4 \quad$ Meer informatie over ISCED-Field 2013 



\section{Arbeidsmarktrendement in de BAMA- structuur}

Tot nu toe is duidelijk geworden dat werkgevers in hun vacatures niet of nauwelijks differentiëren tussen bachelor en master, en hun opleidingseisen blijven formuleren in termen van hbo en wo niveau. De doorstroom van hbo naar wo is eveneens relatief klein ten opzichte van de doorstroom van propedeuse naar bachelor en van bachelor naar master binnen hetzelfde opleidingsniveau. Deze bevindingen roepen nu de vraag op of de economische waarde van deze bachelor en master diploma's op de verschillende opleidingsniveaus gelijk zijn aan elkaar. 1) Is er sprake van een verschil in het arbeidsmarktrendement tussen een diploma (bachelor of master) uit hbo en wo? 2) En in welke mate hebben afwijkende vooropleidingstrajecten een invloed op dit rendement? In dit hoofdstuk geven wij antwoord op deze vragen.

In onze analyses op het arbeidsmarktrendement wordt onderscheid gemaakt tussen twee soorten rendement. Allereerst onderzoeken wij de verschillen in arbeidsmarktstatus van gediplomeerden van een bachelor en master opleiding. De arbeidsmarktstatus maakt een onderscheid tussen werken in loondienst, werken als zelfstandige, een uitkering ontvangen, nog verder studeren, vallen onder een overige categorie of niet meer geregistreerd zijn in Nederland. Deze laatste groep is relevant in verband met de toegenomen internationalisering van het onderwijs. Zo is er een groep studenten die hun vooropleiding niet in het Nederlandse hoger onderwijs hebben gevolgd. Deze studenten hebben hun vooropleiding hoogstwaarschijnlijk in het buitenland gevolgd en zijn daarom niet vindbaar in de Nederlandse registerdata voordat zij beginnen met hun studie in Nederland (Sociaal Economische categorie, SECM). Na diplomering aan een Nederlandse onderwijsinstelling is een aanzienlijk deel van deze groep niet meer terug te vinden in deze data (ruim 37\%). Aannemelijk is dat het hier buitenlandse studenten betreft die zijn geremigreerd en in een ander of in hun thuisland de arbeidsmarkt betreden of doorstuderen. Maar ook studenten die eerst een Nederlandse wo-bachelor propedeuse hebben behaald en vervolgens een wo-bachelor zijn vaak na de bachelor niet meer vindbaar in de administratieve data. Van deze groep is ruim 20\% niet ingedeeld in een sociaaleconomische categorie en bevindt zich mogelijk in het buitenland. Dit kunnen bijvoorbeeld studenten zijn die hun master in het buitenland volgen.

In de tweede stap analyseren we de verschillen in bruto uurloon tussen bachelor en master gediplomeerden die werkzaam zijn in loondienst. Er wordt gebruik gemaakt van administratieve data van CBS en DUO op persoonsniveau voor gediplomeerden die in 
cohortjaar 2012-2013 zijn afgestudeerd. We volgen het rendement van dit cohort voor vijf jaar tot 2018. We observeren het rendement 1 , 2 en 5 jaar na diplomering. ${ }^{5}$

\subsection{Arbeidsmarktstatus}

Tabel 5.1 laat de marginale effecten zien van drie multinomiale logitmodellen waarin de verschillende diploma's in het BAMA-onderwijsstelsel zijn opgenomen als verklarende variabelen voor de arbeidsmarktstatus 1, 2 en 5 jaar na diplomering. In de multinomiale logitmodellen wordt gecorrigeerd voor geslacht en leeftijd.

De tabel laat zien dat wo-bachelors ten aanzien van hbo-bachelors na 1 jaar een 33,6\%punt lagere kans hebben om werknemer in loondienst te zijn en een 1,2\%-punt lagere kans om zelfstandig ondernemer te zijn. Daarentegen hebben deze gediplomeerden vaker een uitkering (o,9\%-punt), maar vooral zijn ze weer terug in het onderwijs ingestroomd (27,3\%-punt). Dit duidt erop dat een wo-bachelor ten opzichte van een hbobachelor door gediplomeerden nog steeds minder vaak als een eindstation wordt gezien.

Wat betreft de masters wordt duidelijk dat de hbo-master door een zeer selectieve groep studenten wordt gevolgd. Hbo-master gediplomeerden zijn significant minder vaak werkzaam als werknemer in loondienst (21,8\%-punt minder vaak werkzaam) en studeren minder vaak door (10,3\%-punt), maar zijn juist vaker (2,9\%-punt) werkzaam als zelfstandige. Wo-masters hebben ten opzichte van hbo-bachelors een $7,7 \%$-punt hogere kans om 1 jaar na diplomering een baan te hebben. Ze zijn daarentegen minder vaak zelfstandig ondernemer en studeren minder vaak door dan hbo-bachelor gediplomeerden. Relevant is tevens dat wo-master gediplomeerden ten opzichte van hbobachelor gediplomeerden een 1,0\%-punt lagere kans hebben op een uitkering.

Vrouwen hebben 1 jaar na diplomering meer kans om te werken en om een uitkering te ontvangen. Daarentegen zijn het juist de mannen die weer terug het onderwijssysteem instromen (1,2\%-punt). Leeftijd is positief gecorreleerd met het ontvangen van een uitkering en zelfstandig ondernemer zijn, maar negatief met het zijn van een student of scholier of werknemer in loondienst.

Als we kijken naar de dynamische effecten, dan zien we dat 2 en 5 jaar na diplomering de student/scholier status steeds minder belangrijk wordt. Hetzelfde geldt voor het hebben van een uitkering. Waar wo-masters 1 jaar na diplomering nog een significante

5 Het overgrote merendeel van de wo-bachelor gediplomeerden behaalt na diplomering nog een ander diploma. Zo behaalt ruim $98 \%$ van de 26766 wo-bachelor gediplomeerden die later nog doorstromen (zij vormen ruim $82 \%$ van alle wo-bachelor gediplomeerden in Nederland in 2012-2013, 18\% stopt na de wo-bachelor of behalen een ander diploma in het buitenland) een wo master in het Nederlandse hoger onderwijs. Dit betekent dat er een zeer kleine groep wo-bachelor gediplomeerden overblijft om te vergelijken met grote groepen als hbo-bachelor en wo-master gediplomeerden. In bijlage 1 staat een overzicht van het arbeidsmarktrendement van de wo-bachelor gediplomeerden (die na 2012-2013 geen ander diploma meer hebben behaald in het Nederlandse hoger onderwijs). 
$1,0 \%$ lagere kans hadden op een uitkering, is dit effect 5 jaar na diplomering niet meer statistisch significant. Echter de kans op werk is nog steeds hoger voor wo-masters. Wo-bachelors behouden echter een comparatief nadeel. De kans om werknemer te zijn blijft structureel lager, terwijl de kans op een uitkering is toegenomen van $0,9 \%$ naar 3,1\% ten opzichte van een hbo-bachelor gediplomeerde. Gediplomeerden die de wo-bachelor dus als eindstation zien, zijn structureel slechter af. Mogelijkerwijs komt dit doordat de wo-bachelors die niet doorstuderen een selectieve groep vormen.

Tabel 5.1

Arbeidsmarktstatus van gediplomeerden in cohort 2012-2013: 1, 2 en 5 jaar na diplomering

\begin{tabular}{|c|c|c|c|c|c|}
\hline $\begin{array}{l}\text { Jaar }+1 \\
\text { (HBO bachelor = ref.) }\end{array}$ & werknemer & zelfstandig & uitkering & $\begin{array}{l}\text { student/ } \\
\text { scholier }\end{array}$ & overig \\
\hline Hbo-associate degree & $\begin{array}{r}-0.029 \\
(0.019)\end{array}$ & $\begin{array}{r}0.039^{* *} \\
(0.014)\end{array}$ & $\begin{array}{r}-0.001 \\
(0.007)\end{array}$ & $\begin{array}{l}-0.004 \\
(0.010)\end{array}$ & $\begin{array}{l}-0.004 \\
(0.009)\end{array}$ \\
\hline Wo-bachelor & $\begin{array}{r}-0.336^{* * *} \\
(0.008)\end{array}$ & $\begin{array}{r}-0.012^{* * *} \\
(0.004)\end{array}$ & $\begin{array}{r}0.009^{* *} \\
(0.003)\end{array}$ & $\begin{array}{r}0.273^{* * *} \\
(0.007)\end{array}$ & $\begin{array}{r}0.066^{* * * *} \\
(0.005)\end{array}$ \\
\hline Hbo-master & $\begin{array}{r}-0.218^{* * *} \\
(0.024)\end{array}$ & $\begin{array}{r}0.279^{* * *} \\
(0.023)\end{array}$ & $\begin{array}{l}-0.007 \\
(0.008)\end{array}$ & $\begin{array}{r}-0.103^{* * *} \\
(0.001)\end{array}$ & $\begin{array}{r}0.048^{* *} \\
(0.015)\end{array}$ \\
\hline Wo-master & $\begin{array}{r}0.077^{* * *} \\
(0.004)\end{array}$ & $\begin{array}{r}-0.021^{* * * *} \\
(0.002)\end{array}$ & $\begin{array}{r}-0.010^{* * * *} \\
(0.001)\end{array}$ & $\begin{array}{r}-0.054^{* * * *} \\
(0.003)\end{array}$ & $\begin{array}{r}0.007^{* * * *} \\
(0.002)\end{array}$ \\
\hline Geslacht (vrouw = 1) & $\begin{array}{r}0.017^{* * * *} \\
(0.003)\end{array}$ & $\begin{array}{r}-0.017^{* * *} \\
(0.002)\end{array}$ & $\begin{array}{r}0.008^{* * *} \\
(0.001)\end{array}$ & $\begin{array}{r}-0.012^{* * * *} \\
(0.002)\end{array}$ & $\begin{array}{r}0.004^{* *} \\
(0.002)\end{array}$ \\
\hline Leeftijd / 100 & $\begin{array}{r}-0.146^{* * *} \\
(0.035)\end{array}$ & $\begin{array}{r}0.325^{* * *} \\
(0.016)\end{array}$ & $\begin{array}{r}0.275^{* * *} \\
(0.010)\end{array}$ & $\begin{array}{r}-0.590^{* * * *} \\
(0.028)\end{array}$ & $\begin{array}{r}0.136^{* * * *} \\
(0.019)\end{array}$ \\
\hline $\mathrm{N}$ & 78.014 & 78.014 & 78.014 & 78.014 & 78.014 \\
\hline $\begin{array}{l}\text { Jaar }+2 \\
\text { (HBO bachelor = ref.) }\end{array}$ & $\begin{array}{r}0.239 \\
\text { werknemer }\end{array}$ & $\begin{array}{r}0.239 \\
\text { zelfstandig }\end{array}$ & $\begin{array}{r}0.239 \\
\text { uitkering }\end{array}$ & $\begin{array}{l}0.239 \\
\text { student/ } \\
\text { scholier }\end{array}$ & $\begin{array}{c}0.239 \\
\text { overig }\end{array}$ \\
\hline Hbo-associate degree & $\begin{array}{r}-0.019 \\
(0.019)\end{array}$ & $\begin{array}{r}0.036^{* *} \\
(0.014)\end{array}$ & $\begin{array}{r}0.004 \\
(0.008)\end{array}$ & $\begin{array}{r}-0.021^{* *} \\
(0.009)\end{array}$ & $\begin{array}{r}-0.001 \\
(0.009)\end{array}$ \\
\hline Wo-bachelor & $\begin{array}{r}-0.259^{* * *} \\
(0.007)\end{array}$ & $\begin{array}{l}-0.003 \\
(0.004)\end{array}$ & $\begin{array}{r}0.015^{* * *} \\
(0.003)\end{array}$ & $\begin{array}{r}0.190^{* * *} \\
(0.006)\end{array}$ & $\begin{array}{r}0.057^{* * *} \\
(0.005)\end{array}$ \\
\hline Hbo-master & $\begin{array}{r}-0.239^{* * *} \\
(0.024)\end{array}$ & $\begin{array}{r}0.316^{* * *} \\
(0.024)\end{array}$ & $\begin{array}{r}-0.014^{* *} \\
(0.007)\end{array}$ & $\begin{array}{r}-0.082^{* * *} \\
(0.001)\end{array}$ & $\begin{array}{r}0.019 \\
(0.012)\end{array}$ \\
\hline Wo-master & $\begin{array}{r}0.085^{* * *} \\
(0.004)\end{array}$ & $\begin{array}{r}-0.023^{* * *} \\
(0.002)\end{array}$ & $\begin{array}{r}-0.009^{* * *} \\
(0.001)\end{array}$ & $\begin{array}{r}-0.056^{* * * *} \\
(0.003)\end{array}$ & $\begin{array}{l}0.003^{*} \\
(0.002)\end{array}$ \\
\hline Geslacht (vrouw = 1) & $\begin{array}{r}0.011^{* * *} \\
(0.003)\end{array}$ & $\begin{array}{r}-0.019^{* * *} \\
(0.002)\end{array}$ & $\begin{array}{r}0.014^{* * *} \\
(0.001)\end{array}$ & $\begin{array}{r}-0.012^{* * *} \\
(0.002)\end{array}$ & $\begin{array}{r}0.007^{* * *} \\
(0.001)\end{array}$ \\
\hline Leeftijd /10 & $\begin{array}{r}-0.282^{* * *} \\
(0.035)\end{array}$ & $\begin{array}{r}0.378^{* * *} \\
(0.018)\end{array}$ & $\begin{array}{r}0.286^{* * *} \\
(0.010)\end{array}$ & $\begin{array}{r}-0.548^{* * *} \\
(0.029)\end{array}$ & $\begin{array}{r}0.166^{* * *} \\
(0.015)\end{array}$ \\
\hline N & 78.014 & 78.014 & 78.014 & 78.014 & 78.014 \\
\hline pseudoR2 & 0.200 & 0.200 & 0.200 & 0.200 & 0.200 \\
\hline
\end{tabular}




\begin{tabular}{|l|r|r|r|r|r|}
\hline $\begin{array}{l}\text { Jaar }+5 \\
\text { (HBO bachelor = ref.) }\end{array}$ & werknemer & zelfstandig & uitkering & $\begin{array}{r}\text { student/ } \\
\text { scholier }\end{array}$ & overig \\
\hline Hbo-associate degree & $-0.033^{*}$ & $0.045^{* *}$ & 0.002 & $-0.011^{*}$ & -0.003 \\
\hline Wo-bachelor & $(0.019)$ & $(0.016)$ & $(0.008)$ & $(0.006)$ & $(0.007)$ \\
\hline Hbo-master & $-0.164^{* * *}$ & $0.012^{* *}$ & $0.031^{* * *}$ & $0.078^{* * *}$ & $0.043^{* * *}$ \\
\hline Wo-master & $(0.007)$ & $(0.005)$ & $(0.004)$ & $(0.004)$ & $(0.004)$ \\
\hline Geslacht (vrouw $=1)$ & $-0.263^{* * *}$ & $0.274^{* * *}$ & $-0.011^{*}$ & $-0.018^{*}$ & $0.018^{*}$ \\
\hline & $(0.025)$ & $(0.023)$ & $(0.007)$ & $(0.010)$ & $(0.011)$ \\
\hline Leeftijd /100 & $0.030^{* * *}$ & $-0.018^{* * *}$ & -0.002 & $-0.021^{* * *}$ & $0.010^{* * *}$ \\
& $(0.003)$ & $(0.002)$ & $(0.001)$ & $(0.001)$ & $(0.002)$ \\
\hline N & 0.003 & $-0.026^{* * *}$ & $0.019^{* * *}$ & $-0.005^{* * *}$ & $0.009^{* * *}$ \\
\hline pseudoR2 & $(0.003)$ & $(0.002)$ & $(0.001)$ & $(0.001)$ & $(0.001)$ \\
\hline
\end{tabular}

Standaardfouten tussen onder de marginale effecten ${ }^{*} p<0.10,{ }^{* *} \mathrm{p}<0.05,{ }^{* * *} \mathrm{p}<0.01$

Bron: CBS-microdata, bewerking ROA

De toegenomen flexibiliteit in het onderwijssysteem betekent dat mensen met meer diverse vooropleidingstrajecten uiteindelijk een hbo- of wo-diploma kunnen halen. De vraag is derhalve ook of de vooropleiding voordat mensen hun hbo-bachelor of wo-masterdiploma kregen nog een additioneel effect heeft op de arbeidsmarktstatus.

Derhalve wordt in figuur 5.1 en 5.2 getoond in welke mate de arbeidsmarktstatus verschilt met de vooropleiding. Figuur 5.1 toont per vooropleiding welke arbeidsmarktstatus hbo-bachelor gediplomeerden hebben op 1, 2 en 5 jaar na diplomering (2014, 2015 en 2018). Hbo-bachelor gediplomeerden die de arbeidsmarkt betreden met een hbopropedeuse als vooropleiding vertonen weinig verschil in arbeidsmarktstatus 1, 2 en 5 jaar na diplomering. Het aandeel werknemers in loondienst blijft stabiel rond $85.5 \%$ en het aandeel zelfstandigen groeit minimaal van $6 \%$ tot bijna $9 \%$. De mensen die twee hbo-bachelor diploma's bezitten zijn vaak werknemer, dit percentage ligt rond de $86 \%$.

De figuren geven ook meer inzicht in de arbeidsmarktkansen die initieel niet geregistreerd stonden in de administratieve data. De hbo-bachelor gediplomeerden wiens vooropleiding niet heeft plaatsgevonden in het Nederlandse hoger onderwijs heeft een vergelijkbare verdeling. Dit kunnen mogelijk mensen zijn, zoals reeds besproken, die vanuit het buitenland komen om in Nederland een opleiding te volgen. Het aandeel zelfstandigen is het grootst onder de groep hbo-bachelor gediplomeerden die hun vooropleiding niet in het Nederlandse hoger onderwijs hebben gevolgd, dit loopt op tot $13 \% 5$ jaar na diplomering. Het percentage werknemers in Nederlandse loondienst van deze groep is kleiner dan de rest, maar in deze groep is gemiddeld 30\% niet beschikbaar in de Nederlandse registerdata na diplomering en is dus waarschijnlijk in het buitenland. 
In het buitenland kunnen deze mensen ook werkzaam zijn (als werknemer of als zelfstandige). Nu er voor deze groep enkel wordt gekeken naar de mensen die beschikbaar zijn in de Nederlandse registerdata, is gemiddeld zo'n 89\% werkzaam (79\% werknemer in loondienst, $10 \%$ zelfstandig).

\section{Figuur 5.1}

Status op Nederlandse arbeidsmarkt voor werkzame, voltijd hbo-bachelor gediplomeerden wiens laatste diploma in ho in cohort 2012-2013 was (per vooropleiding).

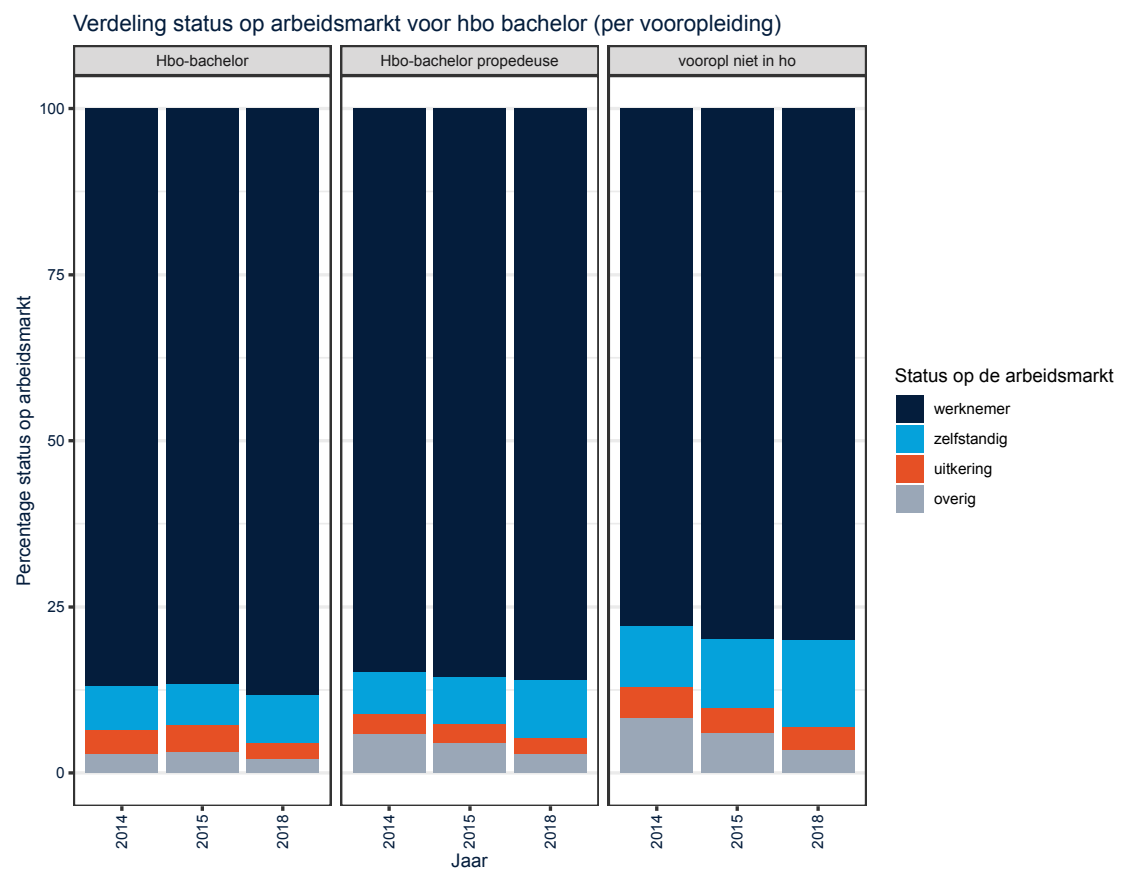

Bron: CBS-microdata, bewerking ROA

In figuur 5.2 wordt de status op de Nederlandse arbeidsmarkt getoond van voltijd wo-master gediplomeerden, uitgesplitst naar vooropleiding. Figuur 5.2 toont vooral een opvallend verschil voor wo-master gediplomeerden die geen Nederlandse vooropleiding hebben gevolgd. In totaal waren er in het cohort gediplomeerden van 2012-2013 ongeveer 7510 wo-master gediplomeerden zonder Nederlandse vooropleiding, waarschijnlijk dus buitenlandse studenten. Dit is bijna $65 \%$ meer dan voor de hbo-bachelor gediplomeerden. Van deze groep gediplomeerden die ervoor kiest om na diplomering in Nederland te blijven, is gemiddeld $73 \%$ werkzaam als werknemer in loondienst en $5 \%$ als zelfstandige. Een groot deel valt ook in de overig-categorie. Een groot aandeel (ruim $50 \%$ ) van deze groep gediplomeerden zijn mogelijk buitenlandse studenten die na het behalen van hun wo-masterdiploma weer vertrekken uit Nederland. De overige vooropleidingen vertonen weinig verschillen in de arbeidsmarktstatus. Met andere woorden, 
de toegenomen flexibiliteit in het vooropleidingstraject speelt uiteindelijk nauwelijks rol. Het is uiteindelijk uitsluitend het laatste diploma dat bepalend is voor de arbeidsmarktstatus.

\section{Figuur 5.2}

Status op Nederlandse arbeidsmarkt voor werkzame, voltijd wo-master gediplomeerden wiens laatste diploma in wo in cohort 2012-2013 was (per vooropleiding).

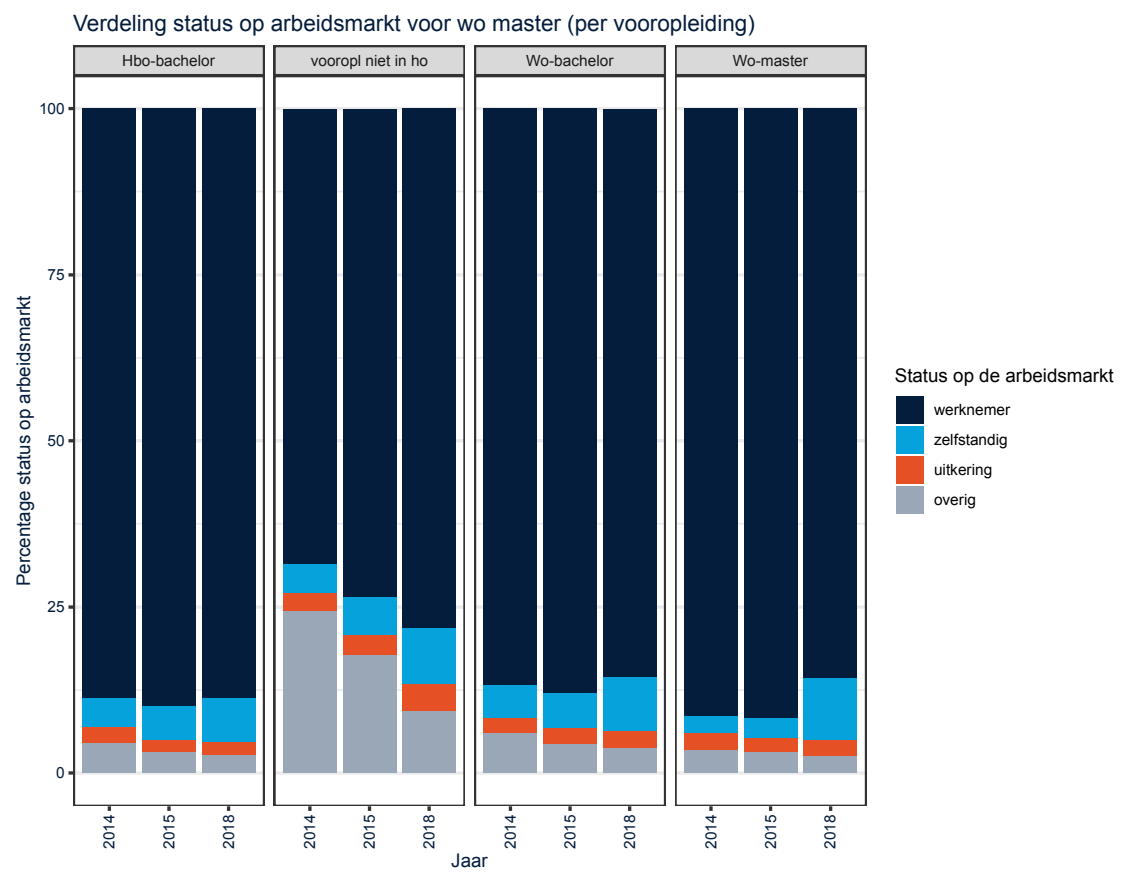

Bron: CBS-microdata, bewerking ROA

\subsection{Bruto uurloon van bachelor en master gediplomeerden}

Tabel 5.2 laat zien hoe de BAMA-diploma's gerelateerd zijn aan het hebben van een loon (dit doen wij omdat voor zelfstandigen geen loon gemeten wordt in de administratieve data, dit toont dus de kans op loon vanuit loondienst of zelfstandige ondernemingen) en de hoogte van het bruto uurloon (wat enkel voor werknemers in loondienst beschikbaar is). We hebben het natuurlijk logaritme van het uurloon genomen zodat de resultaten in percentages geïnterpreteerd kunnen worden. De resultaten in Tabel 5.2 zijn gebaseerd op een linear probability model (LPM) op de kans op het hebben van een salaris en een OLS model op het uurloon. De gemiddelde bruto uurlonen worden berekend door het belastbaar loon te delen door het aantal verloonde uren. 
Tabel 5.2

Loon (In) van gediplomeerden in cohort 2012-2013: 1, 2 en 5 jaar na diplomering

\begin{tabular}{|l|r|r|r|r|r|r|}
\hline $\begin{array}{l}\text { Afhankelijke variabele: } \\
\text { (HBO bachelor = ref.) }\end{array}$ & Kans op loon & Loon (In) & Kans op loon & Loon (In) & Kans op loon & Loon (In) \\
\hline Hbo-associate degree & $-0.053^{* * *}$ & $-0.058^{* * *}$ & $-0.047^{* *}$ & $-0.046^{* *}$ & $-0.061^{* *}$ & $-0.087^{* * *}$ \\
\hline Wo-bachelor & $(0.017)$ & $(0.016)$ & $(0.018)$ & $(0.014)$ & $(0.018)$ & $(0.014)$ \\
\hline Hbo-master & $-0.341^{* * *}$ & $-0.015^{* *}$ & $-0.269^{* * *}$ & $-0.023^{* * *}$ & $-0.177^{* * *}$ & $-0.011^{* * *}$ \\
\hline & $(0.006)$ & $(0.007)$ & $(0.006)$ & $(0.005)$ & $(0.006)$ & $(0.005)$ \\
\hline Wo-master & $-0.304^{* * *}$ & $0.111^{* * *}$ & $-0.320^{* * *}$ & $0.088^{* * *}$ & $-0.307^{* * *}$ & -0.023 \\
\hline N & $(0.018)$ & $(0.19)$ & $(0.018)$ & $(0.018)$ & $(0.018)$ & $(0.018)$ \\
\hline Adjusted R-squared & $0.041^{* * *}$ & $0.155^{* * *}$ & $0.040^{* * *}$ & $0.180^{* * *}$ & 0.001 & $0.222^{* * *}$ \\
\hline & $(0.003)$ & $(0.002)$ & $(0.000)$ & $(0.002)$ & $(0.003)$ & $(0.002)$ \\
\hline
\end{tabular}

Standaard fouten onder de marginale effecten $\mathrm{p}<0.10,{ }^{* *} p<0.05,{ }^{* * *} p<0.01$

Bron: CBS-microdata, bewerking ROA

Uit de tabel blijkt dat, in overeenstemming met Tabel 5.1, de kans op het ontvangen van een loon lager is voor wo-bachelors en hbo-masters (met de kanttekening dat hbomaster gediplomeerden vaker werkzaam zijn als zelfstandigen en dat wij voor hen geen loon waarnemen). Voor wo-masters is deze daarentegen aanzienlijk groter (38\% verschil met wo-bachelor). Opvallend is ook dat dit verschil ook significant blijft over tijd en dus niet volledig verdwijnt. Ten opzichte van hbo-bachelors verdienen wo-masters ongeveer na 5 jaar 22\% meer per uur. Dit is een aanzienlijk verschil in het rendement. Hbo-masters verdienen initieel meer dan hbo-bachelors ( $11 \%$ meer), maar na een periode van 5 jaar is dit verschil niet meer significant. Waarschijnlijk omdat hbo masters hun studie volgend in het kader van hun werk en derhalve eerst een voordeel hadden ten opzichte van voltijds hbo bachelor studenten die wellicht nog besloten om door te studeren of een sabbatical jaar opnamen. Wo-bachelors blijven daarentegen een significant lager loon verdienen dan hbo-bachelors. Na een periode van 5 jaar verdienen zij 1\% minder dan hbo-bachelors. Echter, dit resultaat zegt waarschijnlijk weinig over de waarde van het diploma zelf. Aannemelijk is dat selectiviteit hier een grote rol speelt. De vraag die men daarbij moet stellen is wat de kenmerken zijn van deze wo-bachelors die uiteindelijk niet een wo-master volgen. De kans is groot dat dit studenten zijn die bijvoorbeeld slechter presteerden in het onderwijs of te maken kregen met persoonlijke omstandigheden. Resumerend kan dus worden geconcludeerd dat de hoogte van het opleidingsniveau ook voor het loon nog steeds de meest bepalende factor is en dat het rendement voor de wo-bachelors en de hbo-masters met enige voorzichtigheid moeten worden geïnterpreteerd vanwege de selectiviteit. Het gebrek aan data over het rendement van zelfstandigen maakt het onmogelijk om voor hbo-masters het rendement betrouwbaar in kaart te brengen. 
Tabel 5.3

Gemiddeld bruto uurloon in euro's van gediplomeerden in cohort 2012-2013 1, 2 en 5 jaar na diplomering: vooropleiding. Gecorrigeerd voor inflatie naar 2019

\begin{tabular}{|c|c|c|c|c|}
\hline Vooropleiding & $\begin{array}{l}\text { Behaald ho-diploma } \\
\text { in 2012-2013 }\end{array}$ & $\begin{array}{r}€ \text { Gem. bruto } \\
\text { uurloon } 1 \text { jaar na } \\
\text { diplomering }\end{array}$ & $\begin{array}{r}€ \text { Gem. bruto } \\
\text { uurloon } 2 \text { jaar na } \\
\text { diplomering }\end{array}$ & $\begin{array}{r}€ \text { Gem. bruto } \\
\text { uurloon } 5 \text { jaar na } \\
\text { diplomering }\end{array}$ \\
\hline Hbo-bachelor & Hbo-bachelor & 17,14 & 18,58 & 21,96 \\
\hline $\begin{array}{l}\text { Hbo-bachelor } \\
\text { propedeuse }\end{array}$ & Hbo-bachelor & 15,19 & 16,52 & 20,24 \\
\hline $\begin{array}{l}\text { Vooropleiding niet } \\
\text { in ho }\end{array}$ & Hbo-bachelor & 16,77 & 18,02 & 21,05 \\
\hline
\end{tabular}

Tabellen 5.3, 5.4 en 5.5 laten ten slotte zien dat het loon van gediplomeerden vooral verschilt tussen opleidingsniveaus. De verschillen in het loon van de bachelor en master uitgesplitst naar vooropleiding zijn daarentegen zeer klein. Bij het hbo zijn de uurlonen het hoogst voor de mensen met een dubbele hbo-bachelor. Dit is echter ook een zeer kleine groep met maar 449 mensen in cohort 2012-2013.

Uit tabel 5.4 kan worden opgemaakt dat de uurlonen voor de wo-master het hoogst zijn voor diegene die als vooropleiding ook een wo-masterdiploma hebben behaald. Enkel diegenen met een buitenlandse vooropleiding verdienen meer, maar zijn, zoals eerder geconcludeerd, maar in kleine getalen werkzaam als werknemer in Nederland (ongeveer $33 \%$ versus ongeveer $83 \%$ ). Als er enkel gekeken wordt naar de mensen zonder Nederlandse vooropleiding die na diplomering nog in Nederland zijn, zou zo'n 79\% werkzaam zijn als werknemer of zelfstandige. Verder is het opvallend dat de uurlonen van wo-master gediplomeerden weinig verschillen met hun vooropleiding. Of ze een hbo- of wo-bachelor bezitten als vooropleiding maakt weinig uit.

\section{Tabel 5.4}

Gemiddeld bruto uurloon in euro's van gediplomeerden in cohort 2012-2013 1, 2 en 5 jaar na diplomering: vooropleiding. Gecorrigeerd voor inflatie naar 2019

\begin{tabular}{|c|c|c|c|c|}
\hline Vooropleiding & $\begin{array}{l}\text { Behaald ho-diploma } \\
\text { in 2012-2013 }\end{array}$ & $\begin{array}{r}€ \text { Gem. bruto } \\
\text { uurloon 1 jaar na } \\
\text { diplomering }\end{array}$ & $\begin{array}{r}€ \text { Gem. bruto } \\
\text { uurloon } 2 \text { jaar na } \\
\text { diplomering }\end{array}$ & $\begin{array}{r}€ \text { Gem. bruto } \\
\text { uurloon } 5 \text { jaar na } \\
\text { diplomering }\end{array}$ \\
\hline Hbo-bachelor & Wo-master & 17,20 & 19,20 & 24,93 \\
\hline Wo-bachelor & Wo-master & 17,59 & 19,62 & 25,52 \\
\hline Wo-master & Wo-master & 20,06 & 21,85 & 26,84 \\
\hline $\begin{array}{l}\text { Vooropleiding niet } \\
\text { in ho }\end{array}$ & Wo-master & 20,84 & 22,94 & 28,16 \\
\hline
\end{tabular}

Bron: CBS-microdata, bewerking ROA

We hebben deze uurlonen overigens ook uitgesplitst naar mensen die in hun vervolgopleiding van richting veranderen of niet. Uit deze additionele analyses bleek echter 
dat bij deze opsplitsing slechts marginale verschillen te vinden zijn. Hieruit blijkt dat de laatste opleiding waarmee men de arbeidsmarkt op gaat, het meest relevant is voor verschillen in uurlonen, ongeacht of de vooropleiding in het hbo of wo heeft plaatsgevonden en of er sprake was van een studierichtingswisseling.

\section{Tabel 5.5}

Gemiddeld bruto uurloon in euro's van gediplomeerden in cohort 2012-2013 1, 2 en 5 jaar na diplomering: opleidingsrichting. Gecorrigeerd voor inflatie naar 2019

\begin{tabular}{|c|c|c|c|c|}
\hline Opleidingsniveau & Opleidingsrichting & $\begin{array}{r}€ \text { Gem. bruto } \\
\text { uurloon 1 jaar na } \\
\text { diplomering }\end{array}$ & $\begin{array}{r}€ \text { Gem. bruto } \\
\text { uurloon } 2 \text { jaar na } \\
\text { diplomering }\end{array}$ & $\begin{array}{r}€ \text { Gem. bruto } \\
\text { uurloon } 5 \text { jaar na } \\
\text { diplomering }\end{array}$ \\
\hline \multirow[t]{10}{*}{ Hbo-bachelor } & onderwijs & 15,51 & 16,65 & 19,71 \\
\hline & $\begin{array}{l}\text { vormgeving, kunst, talen en } \\
\text { geschiedenis }\end{array}$ & 12,86 & 14,03 & 18,05 \\
\hline & $\begin{array}{l}\text { journalistiek, gedrag en } \\
\text { maatschappij }\end{array}$ & 13,00 & 14,79 & 18,48 \\
\hline & $\begin{array}{l}\text { recht, administratie, handel en } \\
\text { zakelijke dienstverlening }\end{array}$ & 13,91 & 15,30 & 20,65 \\
\hline & wiskunde, natuurwetenschappen & 14,47 & 15,86 & 20,15 \\
\hline & informatica & 15,47 & 17,39 & 23,16 \\
\hline & techniek, industrie en bouwkunde & 14,58 & 16,00 & 20,85 \\
\hline & $\begin{array}{l}\text { landbouw, diergeneeskunde en } \\
\text {-verzorging }\end{array}$ & 13,54 & 14,55 & 18,35 \\
\hline & gezondheidszorg en welzijn & 15,18 & 16,41 & 19,52 \\
\hline & dienstverlening & 13,02 & 14,32 & 18,80 \\
\hline \multirow[t]{8}{*}{ Wo-bachelor } & onderwijs & 14,92 & 15,59 & 18,52 \\
\hline & $\begin{array}{l}\text { vormgeving, kunst, talen en } \\
\text { geschiedenis }\end{array}$ & 14,42 & 14,93 & 18,52 \\
\hline & $\begin{array}{l}\text { journalistiek, gedrag en } \\
\text { maatschappij }\end{array}$ & 13,55 & 14,45 & 19,34 \\
\hline & $\begin{array}{l}\text { recht, administratie, handel en } \\
\text { zakelijke dienstverlening }\end{array}$ & 15,70 & 16,91 & 22,75 \\
\hline & wiskunde, natuurwetenschappen & 13,93 & 15,62 & 18,70 \\
\hline & informatica & 15,63 & 16,80 & 22,22 \\
\hline & techniek, industrie en bouwkunde & 16,89 & 18,04 & 23,20 \\
\hline & gezondheidszorg en welzijn & 14,72 & 16,41 & 20,55 \\
\hline \multirow[t]{2}{*}{ Hbo-master } & onderwijs & 15,61 & 16,84 & 19,68 \\
\hline & $\begin{array}{l}\text { vormgeving, kunst, talen en } \\
\text { geschiedenis }\end{array}$ & 17,00 & 18,25 & 21,38 \\
\hline \multirow[t]{3}{*}{ Wo-master } & onderwijs & 17,23 & 19,06 & 23,42 \\
\hline & $\begin{array}{l}\text { vormgeving, kunst, talen en } \\
\text { geschiedenis }\end{array}$ & 15,27 & 16,98 & 22,34 \\
\hline & $\begin{array}{l}\text { journalistiek, gedrag en } \\
\text { maatschappij }\end{array}$ & 15,38 & 17,28 & 23,03 \\
\hline
\end{tabular}




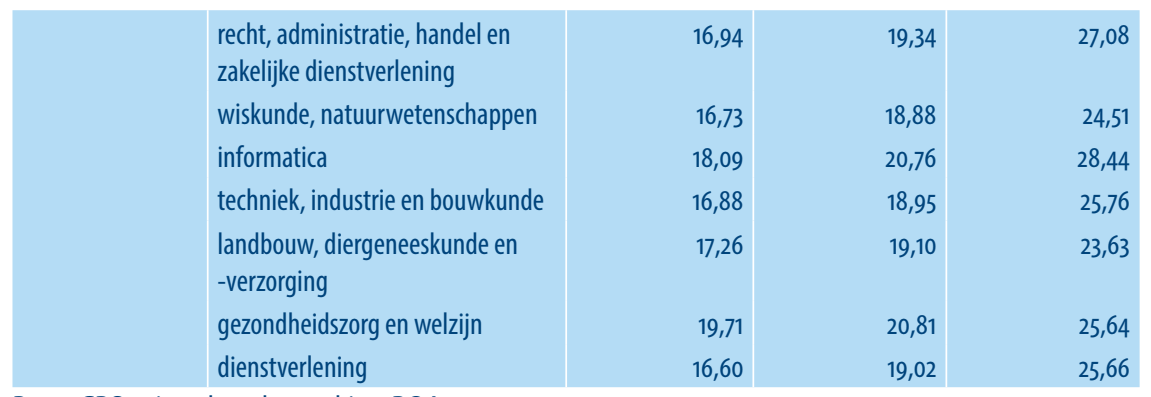

Bron: CBS-microdata, bewerking ROA

Tabel 5.5 laat vervolgens zien dat onderwijsrichtingen eveneens belangrijk zijn voor het loon dat gediplomeerden verdienen, maar ook dat de verschillen in de richtingen per opleidingsniveau kleiner zijn dan de verschillen tussen de opleidingsniveaus. De uitzondering is informatica waarvoor geldt dat hbo-bachelors meer kunnen verdienen dan wo masters die een studie in de richtingen vormgeving, kunst, talen en geschiedenis of een journalistiek, gedrag en maatschappij opleiding hebben gevolgd. Voor wo bachelors bouwkunde zien we eveneens dat zij meer verdienen dan de laatst genoemde wo master richtingen. Echter, voor zowel informatica als bouwkunde geldt dat wo-masters in dezelfde richting een aanzienlijk hoger bruto uurloon hebben. Gediplomeerden in de richting onderwijs verdienen ongeveer even veel, of zij nu een bachelor of een master diploma hebben. 


\section{Conclusie}

In dit rapport werd het arbeidsmarktrendement onderzocht van de verschillende opleidingen in de BAMA-structuur. Het rapport heeft gekeken naar de rol van opleidingsniveaus en de bachelor en masterdiploma's voor de arbeidsmarktvraag. Door middel van tekstmining onderzoek op vacatures van Academic Transfer en Indeed bleek dat werkgevers vooral nog zoeken op basis van de kenmerken van het onderwijssysteem voor de invoering van de BAMA-structuur.

Doordat bachelorsdiploma's van het hbo en wo in theorie een gelijke waarde hebben en een hbo-propedeuse toelating biedt tot een wo-bachelor, is het doorstromen binnen het hoger onderwijs toegankelijker gemaakt, wat ook weer effect kan hebben op het rendement. Dit rapport heeft derhalve op basis van administratieve data van CBS en DUO op persoonsniveau de doorstromingen in kaart gebracht. De resultaten van deze analyse laten zien dat de doorstroom van hbo naar wo relatief klein is ten opzichte van de doorstroom van propedeuse naar bachelor en die van bachelor naar master binnen hetzelfde opleidingsniveau. De BAMA-structuur zorgt wel voor een bewuster keuzemoment voor studenten. Dit resulteert in meer flexibiliteit en vrijheid in het onderwijs, wat ook internationaliteit als gevolg heeft. Toch blijkt dat de doorstroming binnen het onderwijs nog grotendeels loopt zoals in het oude onderwijssysteem.

Vervolgens werd het arbeidsrendement geanalyseerd op basis van administratieve data van CBS en DUO op persoonsniveau. Daarbij hebben we gekeken naar de kans op werk, kans op werken als zelfstandige, de kans op uitkering en het loon dat afstudeerders 1, 2 en 5 jaar na diplomering verdienen. We analyseerden het rendement van bachelors en masters, voor zowel hbo als wo die zijn afgestuurd in cohort 2012-2013. Onze resultaten laten zien dat wo-bachelors ten aanzien van hbo-bachelors na 1 jaar een significant lagere kans hebben om werknemer te zijn of werkzaam te zijn als zelfstandige. Daarentegen hebben deze gediplomeerden vaker een uitkering maar vooral zijn ze weer terug in het onderwijs ingestroomd. Dit duidt erop dat een wo-bachelor in tegenstelling tot een hbo-bachelor niet als eindstation beschouwd wordt.

Wat betreft de masters werd duidelijk dat de hbo-master door een zeer selectieve groep studenten wordt gevolgd. Hbo-master gediplomeerden zijn significant minder vaak werkzaam als werknemer en studeren minder door, maar zijn juist vaker werkzaam als zelfstandige. Wo-masters hebben ten opzichte van hbo-bachelors een $7,7 \%$ hogere kans om 1 jaar na diplomering een baan te hebben. Ze zijn daarentegen minder vaak zelfstandig en studeren minder vaak door dan hbo-bachelor gediplomeerden. 
Wo-master studenten verdienen het meest. Ten opzichte van hbo-bachelors verdienen wo-masters ongeveer na 5 jaar $22 \%$ meer. Dit is een aanzienlijk verschil in het rendement. Hbo-masters verdienen daarentegen beduidend minder dan wo-master gediplomeerden, en ongeveer evenveel als hbo-bachelors gediplomeerden. Voor de wo-bachelor afgestudeerden observeren we dat het loon substantieel lager is. Dit resultaat zegt waarschijnlijk weinig over de waarde van het diploma zelf, maar meer over de selectiviteit van de groep mensen die deze opleidingen volgen. Hierbij moet men de vraag stellen wat de specifieke kenmerken zijn van deze wo-bachelors die uiteindelijk niet een wo-master volgen. De kans is groot dat dit studenten zijn die bijvoorbeeld slechter presteerden in het onderwijs of te maken kregen met persoonlijke omstandigheden tijdens hun studie en daardoor voortijdig hun studie afbraken. Resumerend kan dus worden geconcludeerd dat de hoogte van het opleidingsniveau voor het loon nog steeds de meest bepalende factor is en dat het rendement voor de wo-bachelors en de hbo-masters met enige voorzichtigheid moeten worden geïnterpreteerd vanwege de grote selectiviteit in deze groepen. 


\section{Literatuur}

Bolhaar, J., \& Swart, L. (2020). Flexibiliteit in het hoger onderwijs. CPB, Den Haag.

Bosch-Chapel, L. (2016). Student workload in higher education. If every hour counts.

doi: https://doi.org/10.13140/RG.2.2.33297.07528

Eur-Lex. (2015). Het Bolognaproces: totstandbrenging van de Europese ruimte voor hoger onderwijs. Geraadpleegd op 14-09-2020 van: https://eur-lex.europa.eu/legal-content/ NL/TXT/?uri=LEGISSUM\%3AC11088

Europese Commissie. (z.d.). Het Bolognaproces en de Europese ruimte voor hoger onderwijs. Geraadpleegd op 21-09-2020 van: https://ec.europa.eu/education/policies/highereducation/bologna-process-and-european-higher-education-area $\mathrm{nl}$

Humburg, M., \& van der Velden, R. (2014). Skills and the Graduate Recruitment Process: Evidence from two discrete choice experiments. ROA-RM-14/2. 49. doi: https://doi. org/10.1016/j.econedurev.2015.07.001

Inspectie van het Onderwijs. (2008). Masterjaren tellen. BaMa-onderzoek naar de duur van de Nederlandse. Den Haag.

Inspectie van het Onderwijs. (2019). De Staat van het Onderwijs. Den Haag.

Lipnicka, M. (2016). How was the Bologna Process in Poland, the Netherlands and Flanders implemented? Tertiary Education and Management 22, 359-375.

doi: https://doi.org/10.1080/13583883.2016.1234640

Teelken, C. (2019). The Higher Education System in the Netherlands. In Higher Education System Reform. Leiden, The Netherlands: Brill | Sense. doi: https://doi. org/10.1163/9789004400115 004

Broek, A. van den, Warps, J., Cuppen, J., Termorshuizen, T., \& Lodewick, J. (2020). Monitor Beleidsmaatregelen hoger onderwijs 2019-2020. ResearchNed Nijmegen.

Wihlborg, M., \& Teelken, C. (2014). Striving for Uniformity, Hoping for Innovation and Diversification: A Critical Review concerning the Bologna Process - Providing an Overview and Reflecting on the Criticism. Policy Futures in Education. 12. 1084-1100. doi: https://doi.org/10.2304/pfie.2014.12.8.1084 



\section{Bijlage}

\section{Tabel B.1}

Overzicht arbeidsmarktrendement wo-bachelor gediplomeerden. Gecorrigeerd voor inflatie naar 2019 ( $N=2127$ bij vooropleiding wo-bachelor propedeuse. $N=2974$ bij vooropleiding niet in Nederlands ho)

\begin{tabular}{|c|c|c|c|c|c|c|c|c|}
\hline Vooropleiding & $\begin{array}{l}\text { Behaald } \\
\text { ho-diploma in } \\
2012-2013\end{array}$ & Kans op werk & $\begin{array}{r}\% \\
\text { werk- } \\
\text { zaam } \\
\text { Dec } 2014\end{array}$ & $\begin{array}{r}€ \text { Gem. } \\
\text { bruto } \\
\text { uurloon } \\
2014\end{array}$ & $\begin{array}{r}\% \\
\text { werk- } \\
\text { zaam } \\
\text { Dec } 2015\end{array}$ & $\begin{array}{r}€ \text { Gem. } \\
\text { bruto } \\
\text { uurloon } \\
2015\end{array}$ & $\begin{array}{r}\% \\
\text { werk- } \\
\text { zaam } \\
\text { Dec } 2018\end{array}$ & $\begin{array}{r}€ \text { Gem. } \\
\text { bruto } \\
\text { uurloon } \\
2018\end{array}$ \\
\hline $\begin{array}{l}\text { Wo-bachelor } \\
\text { propedeuse }\end{array}$ & Wo-bachelor & Werknemer & 32.4 & 15.10 & 39.7 & 16.13 & 50.7 & 20.36 \\
\hline $\begin{array}{l}\text { Wo-bachelor } \\
\text { propedeuse }\end{array}$ & Wo-bachelor & Zelfstandig & 5.2 & & 6.5 & & 9.0 & \\
\hline $\begin{array}{l}\text { Wo-bachelor } \\
\text { propedeuse }\end{array}$ & Wo-bachelor & Uitkering & 3.6 & & 3.6 & & 4.2 & \\
\hline $\begin{array}{l}\text { Wo-bachelor } \\
\text { propedeuse }\end{array}$ & Wo-bachelor & $\begin{array}{l}\text { Student/ } \\
\text { scholier }\end{array}$ & 29.2 & & 20.9 & & 7.8 & \\
\hline $\begin{array}{l}\text { Wo-bachelor } \\
\text { propedeuse }\end{array}$ & Wo-bachelor & Overig & 11.3 & & 9.5 & & 5.1 & \\
\hline $\begin{array}{l}\text { Wo-bachelor } \\
\text { propedeuse }\end{array}$ & Wo-bachelor & $\begin{array}{l}\text { Niet in } \\
\text { SECM }\end{array}$ & 18.3 & & 19.7 & & 23.2 & \\
\hline $\begin{array}{l}\text { Vooropleiding } \\
\text { niet in ho }\end{array}$ & Wo-bachelor & Werknemer & 27.5 & 15.73 & 34.0 & 16.58 & 42.0 & 20.91 \\
\hline $\begin{array}{l}\text { Vooropleiding niet } \\
\text { in ho }\end{array}$ & Wo-bachelor & Zelfstandig & 3.0 & & 3.5 & & 5.6 & \\
\hline $\begin{array}{l}\text { Vooropleiding niet } \\
\text { in ho }\end{array}$ & Wo-bachelor & Uitkering & 2.6 & & 2.9 & & 3.8 & \\
\hline $\begin{array}{l}\text { Vooropleiding niet } \\
\text { in ho }\end{array}$ & Wo-bachelor & $\begin{array}{l}\text { Student/ } \\
\text { scholier }\end{array}$ & 21.8 & & 15.2 & & 5.5 & \\
\hline $\begin{array}{l}\text { Vooropleiding niet } \\
\text { in ho }\end{array}$ & Wo-bachelor & Overig & 13.4 & & 10.9 & & 5.7 & \\
\hline $\begin{array}{l}\text { Vooropleiding niet } \\
\text { in ho }\end{array}$ & Wo-bachelor & $\begin{array}{l}\text { Niet in } \\
\text { SECM }\end{array}$ & 31.7 & & 33.5 & & 37.4 & \\
\hline
\end{tabular}

Bron: CBS-microdata, bewerking ROA 
